\title{
Lipid deposition in intestine as a possible cause of malabsorption of nutrients in zinc-deficient common carp (Cyprinus carpio)
}

\author{
BY S. K. TANEJA AND P. ARYA \\ Department of Zoology, Panjab University, Chandigarh-160 014, India
}

(Received 22 November 1993 - Revised 15 February 1994-Accepted 22 February 1994)

\begin{abstract}
An experiment was performed to examine the interaction between $\mathrm{Zn}$ deficiency and lipid intake in carp. The carp were given a high-lipid diet that was either $\mathrm{Zn}$-deficient (ZD) or Zn-supplemented (ZS), or were pair-fed (PF) the ZS diet to the intake of the ZD group. After 8 weeks the carp were killed and measurements were made of intestinal glucose uptake, levels of DNA, RNA and triacylglycerol, and alkaline phosphatase (EC 3.1.3.1) activity in liver and intestine samples. A further group of similar carp were given the same diets but at week 8 were transferred to low-lipid diets, with the exception of half the ZD group. After a further 8 weeks of treatment, carps were killed for biochemical studies. Intestinal $\left[{ }^{14} \mathrm{C} \mid g l u c o s e\right.$ uptake, levels of DNA, RNA and alkaline phosphatase activity in intestine and liver were significantly $(P<0.05)$ lower in the high-lipid ZD group than in the high-lipid ZS and PF diet groups. The triacylglycerol concentration in the intestine was higher in the high-lipid ZD group than in the other two groups. When the carp were given the corresponding low-lipid diets, the variables measured in intestine and liver of the ZD group were close to those of the other groups. The results of this study demonstrate that lipid, when present in excess in the diet, accumulates in the intestine under $\mathrm{Zn}$-deficient conditions and may reduce the absorption of glucose in carp. The reduced RNA and DNA levels and alkaline phosphatase activity in liver and intestine of ZD fish compared with those of ZS fish given highlipid diets is proposed to be due to the malabsorption of nutrients linked with lipid deposition in the intestine, rather than their dependence on the level of $\mathrm{Zn}$ in the diet.
\end{abstract}

Lipid metabolism: Zinc: Malabsorption: Cyprinus carpio

Low feed intake, growth retardation and cataract formation have been reported frequently in fish as consequences of $\mathrm{Zn}$ deficiency (Ogino \& Yang, 1978; Satoh et al. 1983; Richardson et al. 1985). Growth retardation is associated with low feed intake but recent experiments on rats (Koo \& Turk, 1971; Moran \& Lyerly, 1985) have recognized malabsorption as an important factor in the pathogenesis of this disorder.

In one of our recent communications (Taneja et al. 1990) we have reported that a reduction in the lipid content of the basal diet of $\mathrm{Zn}$-deficient fish eliminates anorexia; their feed intake and body weight increase, becoming close to those of the control group. This contradicts earlier reports of the essentiality of $\mathrm{Zn}$ in the regulation of feed intake and subsequent absorption of nutrients and suggests that dietary lipid, rather than the lack of $\mathrm{Zn}$ in diet, contributes to the malabsorption of nutrients under $\mathrm{Zn}$-deficient conditions. We report a study examining $\left[{ }^{14} \mathrm{Clglucose}\right.$ uptake in isolated intestinal segments and the levels of DNA, RNA and alkaline phosphatase (EC 3.1.3.1) activity in intestine and liver of juvenile carp (Cyprinus carpio) after feeding a low-lipid diet for a period of 8 weeks following the induction of $\mathrm{Zn}$ deficiency.

\section{MATERIALS AND METHODS}

A group of 120 juvenile common carp were separated from the main stock and divided into three dietary groups. Each group was further divided into three subgroups to allow them 
Table 1. Composition of diet for carp

\begin{tabular}{lrr}
\hline \hline & Component & 38 \\
\hline & Casein* & 12 \\
Gelatin & 6 \\
Maize oil & 3 \\
Cod-liver oil & 8 \\
Cellulose & 28 \\
Sucrose & 1 \\
& Vitamin mixture & 4 \\
& Mineral mixture & 200 \\
& Water & 300 \\
& Total diet & \\
\hline
\end{tabular}

* Commercial vitamin-free casein was treated with $0.1 \%$ EDTA to remove metal ions including $\mathrm{Zn}^{2+}$, washed twice with water and dehydrated with acetone and ether, before drying overnight at $60^{\circ}$. The resulting granules were powdered.

† The vitamin mixture (Loba Chemie IndoAustrianal Co., Bombay, India) provided (mg/g): ascorbic acid 100 , biotin 0.5 , calcium pantothenate 50 , choline chloride 500 , folic acid $1 \cdot 5$, inositol 200 , menadione 4 , nicotinic acid 75 , pyridoxine hydrochloride 5 , riboflavin 20 , thiamin hydrochloride $5, \alpha$-tocopherol acetate 4 , cyanocobalamin 0.01 .

† The mineral mixture (Loba Chemie IndoAustrianal Co., Bombay, India) provided (g/4 g): $\mathrm{CaH}_{2} \mathrm{PO}_{4} 2 \cdot 58$, $\mathrm{CoCl}_{3} 0.004, \mathrm{CuCl}_{2} 0.01, \mathrm{FeSO}_{4} \cdot 7 \mathrm{H}_{2} \mathrm{O} 0 \cdot 06, \mathrm{MnSO}_{4} \cdot \mathrm{H}_{2} \mathrm{O} 0.08, \mathrm{MgSO}_{4} \cdot \mathrm{H}_{2} \mathrm{O} 0 \cdot 405, \mathrm{KCl} 0 \cdot 343, \mathrm{KI} 0.015, \mathrm{Na}_{2} \mathrm{CO}_{3}$ $0.115, \mathrm{NaF} 0.008, \mathrm{AlCl}_{3} 0.015$.

to be accommodated in plastic portable rectangular tanks each measuring $0.6 \times 0.3 \times 0.5 \mathrm{~m}$ with a water depth of $0.4 \mathrm{~m}$. The temperature of the water supply to the tanks varied between 20 and $30^{\circ} ; \mathrm{pH} \mathrm{7.8-8.0}$; dissolved $\mathrm{O}_{2}, 6-8 \mathrm{ppm} ; \mathrm{HCO}_{3}^{-}$ions, 3-5 ppm; total hardness $\left(\mathrm{CaCO}_{3}\right), 196 \mathrm{mg} / 1 ; \mathrm{Ca}^{2+}$ and $\mathrm{Mg}^{2+}$ ions, $3.93 \mathrm{mg} / \mathrm{l}$ and $\mathrm{Zn}, 0 \cdot 16 \mu \mathrm{g} / \mathrm{l}$. The water of the tank was aerated and circulated continuously throughout the experiment that lasted for 16 weeks. The tank water was changed each week.

\section{Dietary treatment}

Carp were given a high level of dietary lipid $(90 \mathrm{~g} / \mathrm{kg}$, Table 1) for 8 weeks followed by a low level of dietary lipid ( $30 \mathrm{~g} / \mathrm{kg}$; maize oil was omitted) for a further 8 weeks. Within each lipid group carp were divided into three further dietary treatments.

Sixty carp were fed ad lib. on a pelletized Zn-deficient diet (ZD; Table 1) containing 0.5-1.0 ppm Zn; 30 fish were fed ad lib. on a Zn-supplemented diet (ZS) containing $1 \mathrm{~g}$ $\mathrm{ZnSO}_{4} \cdot 7 \mathrm{H}_{2} \mathrm{O} / \mathrm{kg}$ dry diet; the remaining thirty fish were pair-fed the $\mathrm{ZS}$ diet in an amount equal to the average intake of the ZD group during the preceding $24 \mathrm{~h}$. Each group of fish was fed twice a day at 08.00 and 18.00 hours for $2 \mathrm{~h}$ on each occasion. The record of the feed intake was maintained by providing a known amount of the diet to each group in a $100 \mathrm{~mm}$ diameter glass Petri dish. The left over feed was blotted dry and weighed each time before adding fresh diet in the same container. The loss of feed in water, if any, was calculated by keeping the same amount of feed in a water-filled tank without fish for a duration equal to the feeding period.

To ensure that the different ages of the carp fed on the high- and low-lipid diets did not confound the experimental results, thirty fish of the ZD group remained on the high-lipid diet during the second period when the other groups were switched to the low-lipid diet. The 120 carp used in this part of the experiment were reserved exclusively for food intake and growth studies.

Another similar set of 240 carp was reared under the same environmental and feeding 
conditions for biochemical investigations. At the end of the high- and low-lipid treatment periods the carp were starved overnight and killed after feeding for $1 \mathrm{~h}$ the next morning before performing the following tests.

\section{Glucose uptake in intestine}

Intestinal uptake of glucose was measured in the midgut portion by the tissue accumulation method of Crane \& Mandelstam (1960) after the end of the high- and low-lipid dietary treatment periods. A $30 \mathrm{~mm}$ length of the duodenum adjacent to the pylorus was removed from each of six fish from each group after $1 \mathrm{~h}$ of feeding, flushed with $1 \mathrm{M}-\mathrm{NaCl}$ and everted using a thin stainless steel rod. Small rings of the everted intestine were cut and

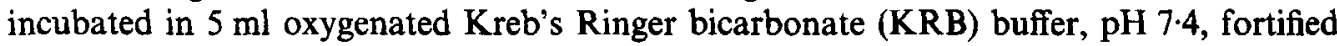
with glucose (5 mM-D-glucose with $0.18 \mathrm{MBq}\left[{ }^{14} \mathrm{C}\right]$ glucose $/ 100 \mathrm{ml} \mathrm{KRB}$ ) at $37^{\circ}$ for $5 \mathrm{~min}$. Since the tropical carp flourishes at $20-30^{\circ}$ and can withstand slightly higher water temperatures, the mammalian conditions for $\left[{ }^{14} \mathrm{C}\right]$ glucose uptake studies were preferred to fish saline $7 \mathrm{~g} \mathrm{NaCl} / 1$. The accumulated radioactivity in the tissue was determined by digesting $50 \mathrm{mg}$ tissue in $0.2 \mathrm{ml} 3.5 \mathrm{M}-\mathrm{KOH}$ (Robinson \& Alvarado, 1971) and dissolving in dioxan-based scintillation cocktail (Butler, 1961) before counting on a KLB 1215 Rockbeta Liquid Scintillation Counter with more than $90 \%$ counting efficiency for ${ }^{14} \mathrm{C}$ isotopes. Extracellular space was measured separately by incubating the tissue in $\left[{ }^{3} \mathrm{H}\right]$ inulin following Alvarado \& Mahmood (1974). After making the necessary correction for extracellular space, the tissue uptake was calculated and expressed as units/g tissue, where one unit represented $1 \mu \mathrm{mol}$ of the substrate taken up per $5 \mathrm{ml}$ at $37^{\circ}$.

\section{Analytical procedures}

Six fish from each of the high- and low-lipid diet subgroups were separated and deprived of feed overnight, then fed for $1 \mathrm{~h}$ on their respective diets the next morning. They were then killed after $1 \mathrm{~h}$ of feeding; liver and small intestine were removed, rinsed in saline $7 \mathrm{~g} \mathrm{NaCl} / 1$ and blotted dry. The tissues of each subgroup were homogenized separately in a glass homogenizer; DNA, RNA and alkaline phosphatase activity were measured in their homogenates. Nucleic acids and protein were extracted by the method of Schneider (1945). DNA, RNA and protein were determined following the procedures of Bradshaw (1966), Schneider (1957) and Lowry et al. (1951) respectively.

The alkaline phosphatase activity was estimated following Bergmeyer (1963). Eighteen more fish from each of the high- and low-lipid diet groups were prepared in a similar manner to that described above. The intestines of six fish from each subgroup were removed each time at intervals of 0,3 and $6 \mathrm{~h}$ of their feeding. Triacylglycerol content was estimated in the intestine by the method of Gottfried \& Rosenberg (1973).

\section{Estimation of $Z n$}

The $\mathrm{Zn}$ level in the intestine was estimated on a Perkin Elmer atomic absorption spectrophotometer after digesting $100 \mathrm{mg}$ fresh tissue in a $22.5 \mathrm{M}-\mathrm{HNO}_{3}-11.6 \mathrm{M}-\mathrm{HClO}_{4}$ $(3: 1, v / v)$ mixture.

\section{Statistical analysis}

The data collected were subjected to two-way ANOVA (Daniel, 1983). The significance between the variants was determined by the $F$ test and was considered significant when the $P$ values were $<0.05$. 


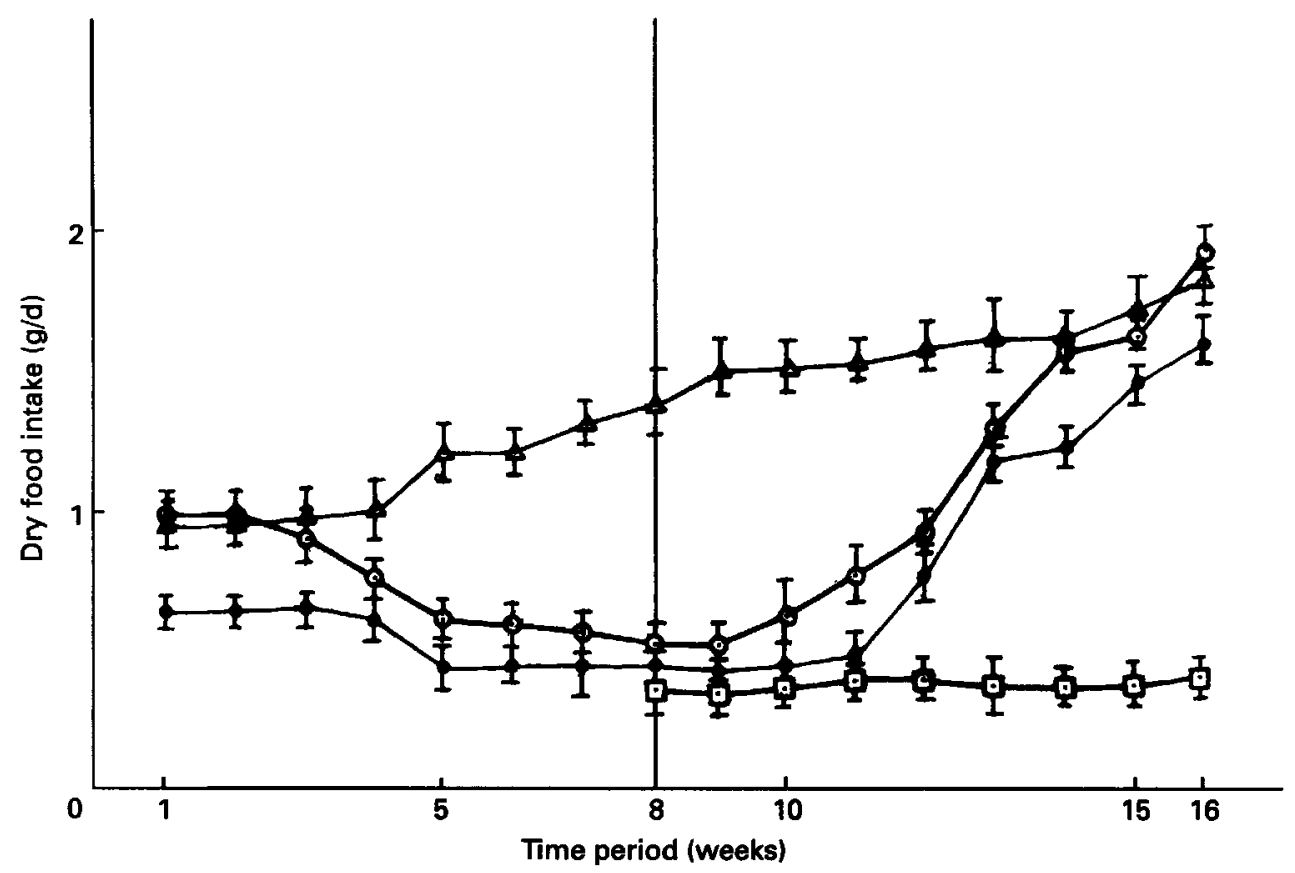

Fig. 1. Mean food intake of Cyprinus carpio fed on diets containing high or low levels of lipid and supplemented with zinc $(\mathrm{ZS} ; \triangle-\triangle)$, deficient in zinc $(\mathrm{ZD} ; \odot-O)$ or pair-fed $(\mathrm{PF} ; \odot-\odot)$ on the ZS diet to the intake of the ZD group. The vertical line at week 8 represents the termination of high-lipid diet feeding and the start of lowlipid diet feeding. One half of the ZD group (口- $\square$ ) continued to receive the high-lipid diet throughout the experiment.

\section{RESULTS}

Feed intake and body weight

The daily feed intake in ZD and ZS groups given the high-lipid diet remained similar during the first 2 weeks of their feeding. During this period, ZD carp consumed $30 \mathrm{~g} / \mathrm{kg}$ body weight per $d$. In week 3 they could consume only the morning ration and the evening ration was left unconsumed. In week 4, their feed intake reduced further, and stabilized at $20 \mathrm{~g} / \mathrm{kg}$ body weight, while ZS fish continued to utilize their usual ration (Fig. 1). The $\mathrm{Zn}$ concentration in the intestine was estimated as 178.9 (SE 6.6), 101.7 (SE 5.5) and 48.2 (SE 3.6) $\mu \mathrm{g} / \mathrm{g}$ fresh tissue in ZS, PF and ZD groups respectively, after 8 weeks of the dietary treatment (Fig. 1).

Fig. 2 depicts body weights at weekly intervals. After 8 weeks of the high-lipid diet the ZD group had lost $12 \cdot 18 \%$ of their body weight in contrast to a negligible loss $(2 \cdot 15 \%)$ in the PF group and a gain of $19.70 \%$ in the ZS group.

On feeding the low-lipid diet to the respective groups during the second period, the feed intake improved in the ZD group. ZD fish consumed $20 \mathrm{~g} \mathrm{diet} / \mathrm{kg}$ body weight per $\mathrm{d}$ from weeks 1 to 3 of the low-lipid period; this increased to $30 \mathrm{~g} / \mathrm{kg}$ in week 4 and to $40 \mathrm{~g} / \mathrm{kg}$ from week 5 onward (Fig. 1). Consequently their body weights increased and approached the level of the ZS group (Fig. 2) after 8 weeks on the low-lipid diet. However, the ZD group maintained on the high-lipid diet for 16 weeks did not exhibit a rise in body weight during the second period of the experiment.

$\mathrm{Zn}$ concentrations recorded in the intestine at the end of the low-lipid dietary period were 175.3 (SE 7.3), 100.8 (SE 8.4) and 50.1 (SE 5.6) $\mu \mathrm{g} / \mathrm{g}$ fresh tissue in ZS, PF and ZD groups respectively. 


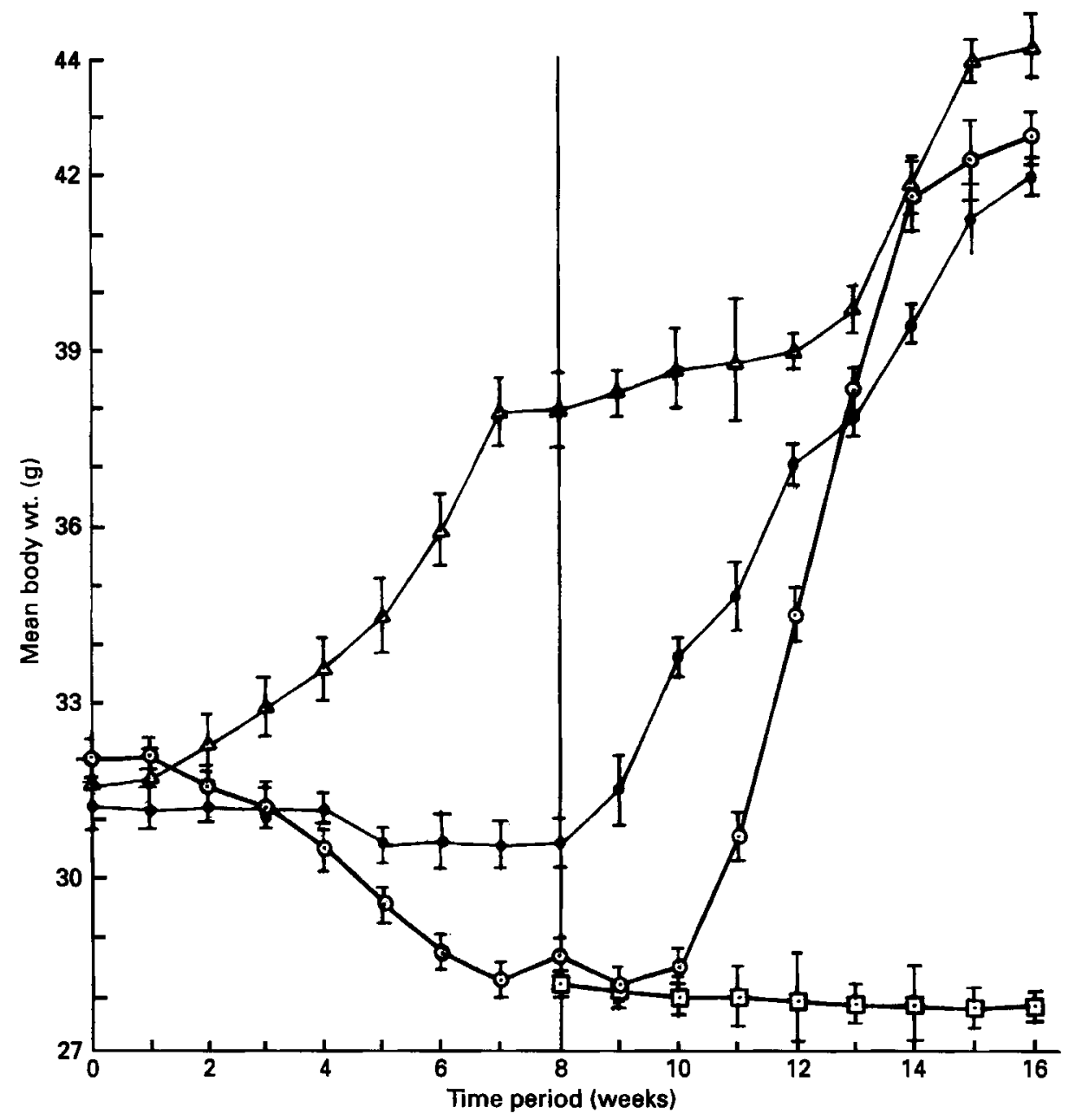

Fig. 2. Mean body weight (g) of carp (Cyprinus carpio) fed on diets containing high or low levels of lipid and supplemented with zinc $(\mathrm{ZS} ; \triangle-\triangle)$, deficient in zinc $(\mathrm{ZD} ; \odot-\odot)$ or pair fed $(\mathrm{PF} ; \bigcirc-\bigcirc)$ the ZS diet to the intake of the $\mathrm{ZD}$ group. The vertical line at week 8 represents the termination of high-lipid diet feeding and the start of low-lipid diet feeding. One half of the ZD group ( $\square-\square$ ) continued to receive the high-lipid diet throughout the experiment.

\section{$\left[{ }^{14} \mathrm{C}\right]$ glucose uptake in the intestine}

The rate of intestinal glucose uptake was significantly lower in the fish fed on the high-lipid ZD diet (Table 2) compared with fish from the ZS and PF diet groups $(P<0.001)$. However, there was no significant difference between these groups in $\left[{ }^{14} \mathrm{C}\right]$ glucose uptake in the intestine when a low-lipid diet was fed during the second period of the experiment.

The $\left[{ }^{14} \mathrm{C}\right]$ glucose uptake by the intestinal segment was not significantly different in the ZD group at 8 and 16 weeks of feeding a high-lipid diet.

\section{Nucleic acids}

Within the ZD group, changes in DNA and RNA concentrations were different for liver and intestine. During the high-lipid period the DNA level in liver of the ZD fish was not 
Table 2. Mean glucose uptake by the intestine, $D N A$ and $R N A$ concentrations and alkaline phosphatase (AP; EC 3.1.3.1) activities in intestine and liver of Cyprinus carpio fed on diets containing high or low lipid and supplemented with zinc $(Z S)$, deficient in zinc $(Z D)$ or pairfed $(P F)$ the ZS diet to the intake of the ZD group*

(Values are means with their standard errors for six fish)

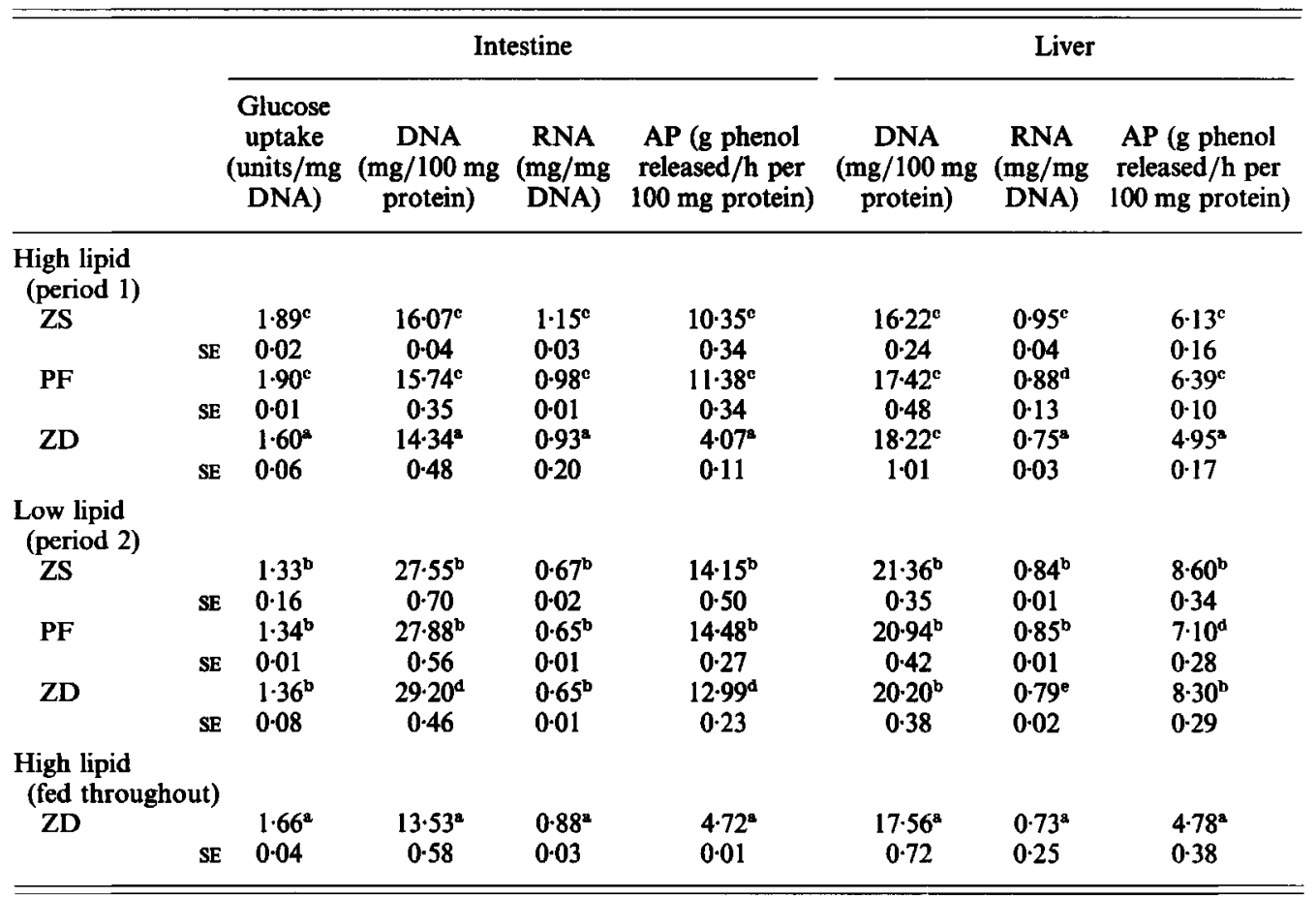

a,b,c,d,e Mean values within a column not sharing a common superscript letter were significantly different $(P<0.05)$.

* For details of diets and procedures, see Table 1 and pp. 754-755.

significantly different from that of the ZS and PF groups (Table 2). In contrast, a reduction of DNA concentration in the intestine of ZD fish fed on the high-lipid diet was observed $(P<0.001)$ compared with ZS and PF diet groups. However, during the low-lipid period the level of intestinal DNA in ZD fish was similar to that in the ZS and PF groups (Table 2).

RNA in the intestine followed the same trend as observed for DNA. Its level decreased in ZD compared with ZS and PF groups during high-lipid intake $(P<0.05)$ and rose in the $Z D$ group during low-lipid intake, approaching the level found in the ZS and PF groups $(P>0.05 ;$ Table 2$)$.

In contrast, the liver RNA concentration in the ZD group fed on the high-lipid diet was lower than that of the ZS and PF groups $(P<0.05)$, and rose only slightly during the lowlipid period (Table 2).

DNA and RNA concentrations in the ZD group fed on the high-lipid diet throughout the experiment were not significantly different at weeks 8 and 16 . 
Table 3. Mean concentration of triacylglycerol $(\mathrm{mg} / \mathrm{mg} D N A) 0,3$ and $6 \mathrm{~h}$ after feeding, in homogenates of intestine of the carp (Cyprinus carpio) fed on high-and low-lipid diets supplemented with zinc $(Z S)$ or deficient in zinc $(Z D)$, or pair-fed $(P F)$ on the $Z S$ diet to the level of the $Z D$ group*

(Values are means with their standard errors for six fish)

\begin{tabular}{|c|c|c|c|c|}
\hline Time (h) after feeding... & & 0 & 3 & 6 \\
\hline $\begin{array}{l}\text { High lipid } \\
\text { (period 1) } \\
\text { ZS } \\
\text { PF } \\
\text { ZD }\end{array}$ & $\begin{array}{l}\text { SE } \\
\text { SE } \\
\text { SE }\end{array}$ & $\begin{array}{l}0.574^{\mathrm{e}} \\
0.002 \\
0.494^{\mathrm{e}} \\
0.007 \\
0.688^{\mathrm{a}} \\
0.003\end{array}$ & $\begin{array}{l}1 \cdot 340^{\mathrm{c}} \\
0 \cdot 021 \\
1 \cdot 116^{\mathrm{e}} \\
0.034 \\
2 \cdot 407^{\mathrm{a}} \\
0 \cdot 264\end{array}$ & $\begin{array}{l}0.955^{\mathrm{c}} \\
0.043 \\
1.064^{\mathrm{e}} \\
0.080 \\
2.296^{\mathrm{a}} \\
0.035\end{array}$ \\
\hline $\begin{array}{l}\text { Low lipid } \\
\text { (period 2) } \\
\text { ZS } \\
\text { PF } \\
\text { ZD }\end{array}$ & $\begin{array}{l}\text { SE } \\
\text { SE } \\
\text { SE }\end{array}$ & $\begin{array}{l}0.302^{\mathrm{b}} \\
0.004 \\
0.303^{\mathrm{b}} \\
0.008^{\mathrm{a}} \\
0 \cdot 366^{\mathrm{d}} \\
0.004\end{array}$ & $\begin{array}{l}0.687^{\mathbf{b}} \\
0.019 \\
0.722^{\mathbf{b}} \\
0.017 \\
0.994^{\mathrm{d}} \\
0.019^{\mathrm{d}}\end{array}$ & $\begin{array}{l}0.530^{\mathbf{b}} \\
0.017 \\
0.526^{\mathrm{b}} \\
0.033 \\
0.605^{\mathrm{d}} \\
0.040\end{array}$ \\
\hline $\begin{array}{l}\text { High lipid } \\
\text { (fed throughout) } \\
\text { ZD }\end{array}$ & SE & $\begin{array}{l}0.620^{\mathrm{a}} \\
0.020\end{array}$ & $\begin{array}{l}2.303^{2} \\
0.041\end{array}$ & $\begin{array}{l}2.270^{8} \\
0.025\end{array}$ \\
\hline
\end{tabular}

a,b,c, d,e Mean values within a column not sharing a common superscript letter were significantly different $(P<0.05)$.

* For details of diets and procedures, see Table 1 and pp. 754-755.

\section{Alkaline phosphatase activity}

Alkaline phosphatase enzyme activities recorded in intestine and liver are given in Table 2. Both intestine and liver displayed a fall in activity in ZD fish compared with ZS and PF groups fed on the high-lipid diet. However, in both liver and intestine of the ZD fish, alkaline phosphatase activity increased during the low-lipid diet period becoming much closer to the activity found in the ZS and PF groups.

The alkaline phosphatase activities in liver and intestine of the ZD fish fed on the highlipid diet were not significantly different after 8 and 16 weeks.

\section{Triacylglycerol}

The triacylglycerol (TG) fraction in the homogenate of the intestine from the ZD group fed on the high-lipid diet was found to be higher by $34.8,63 \cdot 2$ and $103.6 \%$ than in the ZS group, and higher by $45.9,94.6$ and $135.3 \%$ than in the PF group at 0,3 and $6 \mathrm{~h}$ of starvation respectively $(P<0.001$, Table 3$)$. At 0 and $3 \mathrm{~h}$ the TG level was slightly less in PF compared with ZS carp $(P<0.01)$.

Intestinal TG concentration decreased significantly in the $\mathrm{ZD}$ group given the low-lipid diet compared with the ZD group given the high-lipid diet. It was still higher in ZD compared with ZS and PF groups but was less than that of ZS and PF groups fed on highlipid diets at corresponding stages of starvation. 


\section{DISCUSSION}

The amount of feed eaten by carp in the high-lipid ZD group was lower than that in the high-lipid ZS group, and this evidently resulted in a lower rate of weight gain in the ZD group. The carp in the high-lipid PF group gained more body weight than those of the ZD group despite equal feed intake. This differential gain in body weight of ZD and PF groups given high-lipid diets may reflect a difference in the level of intestinal absorption of nutrients between the two groups. The reduction of lipid in the diet during the second period stimulated an increase in feed consumption by the $Z D$ carp and resulted in restoration of their body weight to a level close to that of the ZS group despite $\mathrm{Zn}$ deficiency. The almost identical body weights of the ZD, ZS and PF groups at the end of the second period, irrespective of $\mathrm{Zn}$ concentration in their diet/tissues, suggest that nutrient absorption was no longer impaired in the ZD carp given a low-lipid diet. This implies that defects in feed consumption, reduction in body weight and malabsorption of lipid in ZD carp during the first period of the experiment were interlinked and depended upon the dietary fat level.

The specific role of lipids in eliciting the defects becomes evident on examining the intestinal TG level which was higher in ZD carp given the high-lipid diet than in those fed on the low-lipid diet. This suggests that TG transport from the mucosal epithelium was relatively slow in ZD compared with ZS and PF carp fed on the high-lipid diet. This is consistent with the reports of Koo \& Turk (1977) in rats and Taneja et al. (1990) in carp, who concluded that TG deposition in the mucosal epithelium was a result of its lower transformation to chylomicrons and their subsequent slower transport to extracellular spaces. Taneja et al. (1990) suggested that intestinal TG deposition might be the cause of anorexia because of its inhibitory effect on the stomach emptying process through a feedback mechanism which they determined by estimating feed intake and stomach clearance rate in ZD carp fed on high- and low-fat diets.

That TG deposition contributed to malabsorption is suggested by the data for $\left[{ }^{14} \mathrm{C}\right]-$ glucose uptake in the intestine which reflect an inverse relationship between the two. High intestinal TG concentration during the high-lipid period caused a reduction of intestinal $\left[{ }^{14} \mathrm{C}\right]$ glucose uptake in ZD carp, whereas the opposite was true during the low-lipid period. In contrast, Reeves \& O'Dell (1983), Ghishan (1984) and Southon et al. $(1984,1986)$ did not find a significant difference in the uptake of radiolabelled hexose by the mucosa of ZD and ZS rats. The divergent results for hexose uptake obtained in our high-lipid-fed carp and those of others can be attributed to the difference in the degree of TG concentration in the mucosal epithelium. In the studies using starved rats there was a complete lack of intestinal TG accumulation in $\mathrm{Zn}$-deficient animals whereas we studied hexose uptake in carp when TG accumulation was observed. The reduction of TG accumulation in $\mathrm{ZD}$ carp given the low-lipid diet during the second period elicited a rise in intestinal hexose uptake to a level close to that of the ZS carp. This result is in agreement with that reported by the above investigators in fasted rats, which thus lends support to our findings.

The idea that the malabsorption of nutrients associated with $\mathrm{Zn}$ deficiency is a consequence of $\mathrm{TG}$ deposition in the intestine is further supported by the observed lower concentrations of intestinal and liver DNA and RNA in ZD than in ZS and PF carp fed on a high-lipid diet, and their reversal in $\mathrm{ZD}$ carp fed on a low-lipid diet during the second period. The difference in the concentration of nucleic acids between the two ZD groups of carp demonstrates the impact of the level of feed intake and subsequent absorption of nutrients on nucleic acid synthesis and does not support the essentiality of $\mathrm{Zn}$ in their synthesis. The concept that $\mathrm{Zn}$ is involved in the synthesis of nucleic acids possibly emanated from the recorded lower levels of DNA and RNA (Mills et al. 1969; Somers \& 
Underwood, 1969; Sandstead et al. 1971; Prasad et al. 1971; Im et al. 1975) and lower activities of enzymes associated with their synthesis (Prasad \& Oberleas, 1974; Im et al. 1975) which in fact may be a response to low nutrient concentrations in the tissues due to malabsorption, rather than to a low concentration of $\mathrm{Zn}$.

The intestinal and liver alkaline phosphatase activities were also lower in ZD compared with ZS and PF carp fed on the high-lipid diet; however, when the low-lipid diet was fed during the second period the enzyme activity in the ZD carp rose and approached that of the ZS and PF groups. Leucke et al. (1968), Iqbal (1971), Williams (1972) and Adeniyi \& Heaton (1980) observed a reduction in alkaline phosphatase activity in ZD rats and remarked that the reduction of enzyme activity in them was neither due to the lack of $\mathbf{Z n}^{2+}$ ions in the tissues nor to inanition but rather to the lowered concentration of the enzyme itself. This conclusion seems to be based upon the comparison of enzyme activity between $\mathrm{ZD}$ rats fed $a d l i b$. and diet-restricted ZS rats using different substrates with and without $\mathrm{Zn}$ in the incubation medium. These investigators did not consider the level of nutrients in the tissues. Had $\mathrm{Zn}$ concentration been the sole rate-limiting factor as suggested by these workers then enzyme activity in the tissue would have remained unaltered in ZD carp when the lipid content of the diet was decreased. Instead, the enzyme activity was higher than that of ZD carp fed on a high-lipid diet and closer to that of the ZS and PF carp. The recovery of enzyme activity in the ZD fish fed on the low-lipid diet and not in the ZD carp fed on the high-lipid diet provides evidence that the rate of enzyme synthesis in the tissue depends on the availability of nutrients. The inverse relationship of enzyme activity to TG deposition and its direct relationship to intestinal $\left[{ }^{14} \mathrm{C}\right]$ glucose uptake in ZD carp fed on high- and low-lipid diets provide strong evidence against the dependence of enzyme synthesis on the availability of $\mathrm{Zn}$ to the tissue, but support the idea that malabsorption of nutrients due to accumulation of intestinal TG is the cause of reduced enzyme activity in ZD carp fed on a high-lipid diet.

Our results, therefore, provide strong evidence in favour of the essentiality of $\mathrm{Zn}$ for the absorption of dietary lipids when they are present in excess in the diet. The lower uptake of nutrients in carp fed on a high-lipid ZD diet results from the accumulation of lipid in the intestine due to an unknown defect in their transport mechanism. The reported lower levels of DNA, RNA and alkaline phosphatase activity are a reflection of low absorption of nutrients linked with lipid deposition in the intestine rather than their dependence on the $\mathrm{Zn}$ level in the tissues.

\section{REFERENCES}

Adeniyi, F. A. \& Heaton, F. W. (1980). The effect of zinc deficiency on alkaline phosphatase $(E C$ 3.1.3.1) and its isoenzymes. British Journal of Nutrition 43, 561-569.

Alvarado, F. \& Mahmood, A. (1974). Co-transport of organic solutes and sodium ions in the small intestine: a general model. Amino acid transport. Biochemistry 13; 2882-2890.

Bergmeyer, H.-U. (1963). Phosphates (phosphomonoesterases). Determination in serum with $p$-nitrophenylphosphate. In Methods of Enzymatic Analysis, pp. 783-785 [H.-U. Bergmeyer, editor]. New York: Academic Press.

Bradshaw, L. J. (1966). Introduction to Molecular Biological Techniques, pp. 135-137. Englewood Cliffs, NJ: Prentice Hall.

Butler, F. E. (1961). Determination of tritium in water and urine. Liquid scintillation counter and rate of drift determination. Annals of Chemistry 33, 409-413.

Crane, R. K. \& Mandelstam, P. (1960). The active transport of sugars by various preparations of hamster intestine. Biochimica et Biophysica Acta 45, 460-476.

Daniel, W. W. (1983). Biostatistics: A Foundation for Analysis in the Health Sciences, 3rd ed, pp. 67-87 [W. W. Daniel, editor]. New York: John Wiley \& Sons.

Ghishan, F. K. (1984). Transport of electrolytes, water and glucose in zinc deficiency. Journal of Pediatric Gastroenterology and Nutrition 3, 608-612.

Gottfried, S. P. \& Rosenberg, B. (1973). Improved manual spectrophotometric procedure for determination of serum triglycerides. Clinical Chemistry 19, 1077-1078. 
Im, M. J. C., Hsu, J. M. \& Hoopes, J. E. (1975). Enzyme activities in the epidermis of zinc-deficient rats. Journal of Nutrition 105, 1391-1394.

Iqbal, M. (1971). Activity of alkaline phosphatase and carbonic anhydrase in male and female zinc-deficient rats. Enzyme 12, 33-40.

Koo, S. I. \& Turk, D. E. (1977). Effect of zinc-deficiency on intestinal transport of triglyceride in the rat. Journal of Nutrition 107, 909-919.

Lowry, O. H., Rosebrough, N. J., Farr, A. L. \& Randall, R. J. (1951). Protein measurement with the Folin-phenol reagent. Journal of Biological Chemistry 193, 265-275.

Luecke, R. W., Olman, M. E. \& Baltzer, B. V. (1968). Zinc deficiency in the rat: effect on serum and intestinal alkaline phosphatase activities. Journal of Nutrition 94, 344-350.

Mills, C. F., Quarterman, J., Chesters, J. K., Williams, R. B. \& Dalgarne, A. C. (1969). Metabolic role of zinc. American Journal of Clinical Nutrition 22, 1240-1249.

Moran, J. R. \& Lyerly, A. (1985). The effects of severe zinc deficiency on intestinal amino acid losses in the rat. Life Sciences 36, 2515-2521.

Ogino, C. \& Yang, G. Y. (1978). Requirement of rainbow trout for dietary zinc. Bulletin of the Japanese Society of Scientific Fisheries 44, 1015-1018.

Prasad, A. S. \& Oberleas, D. (1974). Thymidine kinase activity and incorporation of thymidine into DNA in zincdeficient tissue. Journal of Laboratory and Clinical Medicine 83, 634-639.

Prasad, A. S., Oberleas, D., Miller, E. K. \& Leack, R. W. (1971). Biochemical effects of zinc-deficiency: changes in activities of zinc-dependent enzymes and ribonucleic acid and deoxyribonucleic acid content of tissues. Journal of Laboratory and Clinical Medicine 77, 144-152.

Reeves, P. G. \& O'Dell, B. L. (1983). The effect of zinc deficiency on glucose metabolism in meal-fed rats. British Journal of Nutrition 49, 441-451.

Richardson, N. L., Higgs, D. A., Beames, R. M. \& McBride, R. J. (1985). Influence of dietary calcium, phosphorus, zinc and sodium phytate level on cataract incidence, growth and histopathology in juvenile chinook salmon (Onchorhynchus tshawytscha). Journal of Nutrition 115, 553-567.

Robinson, J. W. L. \& Alvarado, F. (1971). Interaction between the sugar and amino-acid transport systems at the small intestinal brush border: a comparative study. Pfluegers Archives 326, 48-75.

Sandstead, H. H., Terhune, M., Brady, R. W., Gillespie, D. \& Hollaway, W. J. (1971). Zn-deficiency: brain DNA, protein, lipid and liver ribosome and RNA polymerase. Clinical Research 19, 83-90.

Satoh, S., Yamamoto, H., Takeuchi, H. \& Watanabe, H. (1983). Effects of growth and mineral composition of rainbow trout by deletion of trace elements or magnesium from fish meal diet. Bulletin of the Japanese Society of Scientific Fisheries 49, 425-429.

Schneider, W. C. (1945). Phosphorus compounds in animal tissue. Extraction and estimation of deoxypentose nucleic acid and pentose nucleic acid. Journal of Biological Chemistry 161, 293-303.

Schneider, W. C. (1957). Determination of nucleic acids in tissues by pentose analysis. In Methods in Enzymology vol. 3, pp. 680-684. New York: Academic Press.

Somers, A. L. \& Underwood, E. J. (1969). Ribonuclease activity and nucleic acids and protein metabolism in testis of Zn-deficient rats. Australian Journal of Biological Sciences 22, 1277-1282.

Southon, S., Gee, J. M. \& Johnson, I. T. (1984). Hexose transport and mucosal morphology in the small intestine of the zinc-deficient rat. British Journal of Nutrition 52, 371-380.

Southon, S., Gee, J. M. \& Johnson, I. T. (1986). Hexose absorption from jejunal loops in situ in $\mathrm{Zn}$-deficient and Zn-supplemented rats. British Journal of Nutrition 55, 193-200.

Taneja, S. K., Lath, A. \& Arya, P. (1990). Lipid malabsorption as a possible cause of anorexia in $\mathrm{Zn-deficient}$ juvenile common carp, Cyprinus carpio. Aquaculture 89, 327-335.

Williams, R. B. (1972). Intestinal alkaline phosphatase and inorganic pyrophosphatase activities in zinc-deficient rat. British Journal of Nutrition 27, 121-130. 